\title{
Penggunaan Model Pembelajaran Kooperatif Tipe Students Teams Achievement Divisions (STAD) untuk Meningkatkan Hasil Belajar Jasa Boga Materi Pengolahan Soup
}

\author{
Eni Kusumastuti ${ }^{1 *}$ \\ ${ }^{1}$ SMKN 1 Dlanggu, Mojokerto, Indonesia
}

A R T I C L E I N F O

Article history:

Received 11 February

2021

Received in revised form 22 March 2021

Accepted 10 April 2021

Available online 15 May

2021

Kata Kunci:

Pengolahan Soup, Tata

Boga, STAD

Keywords:

Soup Processing, Catering,

STAD

\begin{abstract}
A B S T R A K
Pelaksanaan pembelajaran yang masih berpusat pada guru menyebabkan siswa merasa bosan, dan kurang dilibatkan dalam kegiatan pembelajaran, sehingga diperlukan penggunaan model pembelajaran yang efektif didalam sebuah pembelajaran. Tujuan penelitian ini adalah menanalisis penggunaan model pembelajaran STAD untuk meningkatkan hasil belajar jasa boga materi pengolahan soup siswa. Penelitian ini termasuk jenis penelitian tindakan kelas. Subjek penelitian adalah hasil belajar Jasa Boga Materi Pengolahan Soup yaitu siswa kelas XI. Teknik pengumpulan data dengan memberikan tes hasil belajar kepada siswa. Teknik analisis data yang digunakan adalah analisis statistik deskriptif kuantitatif. Hasil penelitian menunjukkan hasil nilai tes formatif siswa dalam siklus 2 memperoleh rata-rata 83,33 , lebih tinggi dari pada sebelum siswa diajar dengan model pembelajaran lainnya, memperoleh rata-rata 62,67. Simpulan penelitian ini adalah penerapan model pembelajaran kooperatif tipe STAD dapat meningkatkan perolehan hasil belajar siswa pada materi
\end{abstract} pengolahan soup dari pada dengan model pembelajaran lainnya. Implikasi penelitian ini adalah dengan perlakuan model STAD dapat mendorong siswa untuk lebih aktif dalam proses pembelajaran, menumbuhkan rasa ingin tahu siswa, dan melatih kemampuan berpikir siswa.

\begin{abstract}
A B S T R A K
The implementation of learning that is still teacher-centered causes students to feel bored, and is less involved in learning activities, so it is necessary to use an effective learning model in learning. The purpose of this study was to analyze the use of the STAD learning model to improve student learning outcomes of food processing services for soup processing materials. This research is a classroom action research. The research subjects were the learning outcomes of Soup Processing Materials Catering Services, namely students of class XI. The technique of collecting data is by giving learning outcomes tests to students. The data analysis technique used is kuantitative descriptive statistical analysis. The results showed that the results of the formative test scores of students in cycle 2 obtained an average of 83.33, higher than before students were taught by other learning models, obtaining an average of 62.67. The conclusion of this research is that the application of the STAD type of cooperative learning model can improve the acquisition of student learning outcomes on soup processing material than with other learning models. The implication of this research is that the STAD model treatment can encourage students to be more active in the learning process, foster student curiosity, and train students' thinking skills.
\end{abstract}

\section{Pendahuluan}

Meningkatkan kualitas pendidikan pada dasarnya tidak terlepas dari proses belajar mengajar. Proses belajar mengajar pada hakikatnya adalah proses komunikasi yang di dalamnya terdapat berbagai kegiatan, salah satu diantaranya adalah penyampaian materi pelajaran (Maulida, M., Wati \& An'nur, 2015; 
Morelent \& Syofiani, 2018; Prasetyo et al., 2016). Pendidikan merupakan suatu kekuatan yang dinamis dalam kehidupan setiap individu, yang mempengaruhi perkembangan fisiknya, daya jiwanya (akal, rasa, dan kehendak), sosialnya dan moralitasnya (Arwanda et al., 2020; Purwanti, 2017; Wahyudin, 2018). Pendidikan dapat diartikan sebagai seluruh kegiatan yang direncanakan dengan materi yang terorganisasi, dilaksanakan secara terjadwal dalam sistem pengawasan dan diberikan evaluasi berdasarkan pada tujuan yang telah ditentukan.

Kegiatan belajar mengajar merupakan kegiatan utama dalam keseluruhan proses pendidikan di dalam kelas. Keberhasilan pencapaian tujuan pendidikan banyak bergantung pada kualitas pelaksanaan proses belajar mengajar. Proses belajar mengajar di dalam sekolah sangat dipengaruhi oleh kegiatan atau cara dan metode yang digunakan oleh guru. Metode pendidikan adalah cara-cara yang dipakai oleh guru atau sekelompok orang untuk membimbing anak atau peserta didik sesuai dengan perkembangannya ke arah tujuan yang hendak dicapai (Esminarto et al., 2016; Hazmiwati, 2018; Yuliarni et al., 2013). Kemampuan guru dalam menyampaikan materi menjadi hal penting dalam proses belajar mengajar. Munculnya banyak hambatan baik dari pihak siswa maupun pihak guru sebagai pendidik terkait dengan model pembelajaran dalam penerapan pembelajaran. Model pembelajaran yang bervariasi dapat membuat siswa merasa senang dan lebih aktif mengikuti kegiatan pembelajaran yang dilaksanakan (Rahmadani et al., 2018; Viviyung, 2015; Wahyuni, 2019).

Berdasarkan observasi yang dilakukan oleh peneliti, permasalahan yang dihadapi dalam pembelajaran Kompetensi Keahlian Tata Boga SMK Negeri 1 Dlanggu Kabupaten Mojokerto adalah pembelajaran tersebut masih menggunakan model pembelajaran ceramah yang relatif mudah dan sederhana untuk diterapkan. Didukung dengan hasil wawancara dengan guru mata pelajaran Produktif TB di SMK Negeri, dapat diketahui bahwa kegiatan pembelajaran mata pelajaran Produktif TB masih menggunakan metode ceramah, pembelajaran masih didominasi oleh guru dan kurang terpusat pada siswa. Siswa hanya diberi tugas dan berdiskusi pada bagian materi tertentu saja. Hal ini menyebabkan siswa kurang merespon selama kegiatan pembelajaran berlangsung karena siswa merasa bosan, jenuh, mengantuk dan kurang dilibatkan dalam kegiatan pembelajaran. Siswa menganggap bahwa apa yang disampaikan guru sudah banyak tanpa mereka berinisiatif untuk mencoba memecahkan masalah. Mereka hanya bergantung pada penyampaian materi guru yang berlanjut sampai mereka lulus. Hal ini berpengaruh pada hasil belajar siswa yang menjadi kurang optimal dalam mencapai ketuntasan belajar.

Proses pembelajaran pada mata pelajaran pengolahan dan penyajian makanan siswa cenderung pasif, seperti rendahnya keingintahuan siswa untuk bertanya, siswa masih merasa kurang percaya diri dalam melakukan praktik, siswa belum berani saat disuruh presentasi di depan kelas untuk memaparkan hasil praktik, kurangnya komunikasi dengan guru maupun teman, sehingga hasil belajar siswa rendah, hal ini dapat dilihat dari hasil nilai rata-rata UAS pada semester 1 sebesar 54,95. Dari 35 siswa hanya 15 atau 46,87\% siswa yang mencapai KKM (Kriteria Ketuntasan Minimum). Pembelajaran pengolahan soup merupakan sebuah pembelajaran yang bertujuan agar siswa memahami jenis soup yang berfungsi sebagai makanan pembuka, yaitu soup dalam keadaan bening (clear) maupun kental (thick) (Astuti et al., 2016; Febriana, 2017; Masdarini \& Devi, 2012). Dalam menyelesaikan masalah tersebut, perlu diterapkan strategi pembelajaran yang inovatif yaitu salah satunya dengan menerapkan model pembelajaran kooperatif tipe Student Teams Achievement Divisions (STAD).

Model pembelajaran kooperatif tipe Students Teams Achievement Divisions (STAD) adalah suatu metode pembelajaran yang melakukan pemusatan pada pengajaran dan ketrampilan memecahkan masalah, yang diikuti dengan penguatan ketrampilan (Nurhazannah, 2017; Suratno, 2013; Viviyung, 2015). Penggunaan model pembelajaran yang bervariasi dirasa mampu untuk meningkatkan semangat peserta didik dalam mengikuti proses belajar mengajar, karena dengan pembelajaran secara kooperatif semaksimal mungkin partisipasi siswa dalam memperoleh pengetahuan sangat diperlukan.

Metode pengajaran yang akan diterapkan harus memperhatikan sasaran atau subyek pelaku tindakan. Subyek penellitian ini adalah siswa SMK dimana mereka termasuk dalam kategori remaja. (Faridah et al., 2016; Maharani, 2017; Rudyanto, 2016) siswa pada kategori remaja cenderung bersifat ingin mandiri, ingin segala sesuatunya serba bebas, menuntut kreativitas, ingin dihargai sebagai anak gede yang tidak mau dikungkung tetapi ingin bebas. Oleh karena itu, metode pembelajaran yang menjadi alternatif pilihan dan dapat diterapkan pada siswa SMK. Kelebihan dari model pembelajaran kooperatif tipe Students Teams Achievement Divisions (STAD) adalah (1) mendorong siswa untuk lebih aktif dalam proses pembelajaran, (2) dapat menumbuhkan rasa ingin tahu siswa, (3) melatih kemampuan berpikir siswa dalam memecahkan masalah, (4) menumbuhkan interaksi antar siswa menunjukan bahwa model pembelajaran tersebut dapat meningkatkan hasil belajar siswa (Kristin, 2016; Sofianti et al., 2013; Wardani, 2015). Hal ini menunjukan bahwa model pembelajaran tersebut dapat meningkatkan aktivitas dan hasil belajar siswa, dengan menerapkan model pembelajaran kooperatif tipe Students Teams Achievement Divisions (STAD) maka siswa akan lebih aktif dan kreatif dalam memecahkan masalah yang 
dihadapi dalam pembelajaran, dapat meningkatkan ingatan yang lebih kepada siswa mengenai materi pembelajaran yang telah disampaikan, siswa lebih memahami isi materi yang diajarkan karena siswa terlibat langsung dalam proses pembelajaran sehingga hasil belajar siswa akan meningkat.

Penelitian ini didukung dengan beberapa penelitian yang relevan seperti: (1) penelitian yang dilaksanakan oleh (Rahmadani et al., 2018), yang memperoleh hasil bahwa Berdasarkan hasil pengembangan bahan ajar diperoleh modul matematika berbasis model kooperatif tipe STAD dengan metode penemuan terbimbing yang valid, praktis, dan efektif; (2) penelitian yang dilaksanakan oleh (Viviyung, 2015), yang memperoleh hasil bahwa penggunaan model pembelajaran kooperatif tipe STAD dapat meningkatkan hasil belajar PKn; (3) penelitian yang dilaksanakan oleh (Febriana, 2017), yang memperoleh hasil bahwa model pembelajaran berbasis kompetensi dengan pendekatan dunia kerja pada program D3 Tata Boga efektif untuk digunakan didalam proses pembelajaran.

Tujuan penelitian ini adalah menanalisis penggunaan model pembelajaran Kooperatif Tipe Students Teams Achievement Divisions (STAD) untuk meningkatkan hasil belajar jasa boga materi pengolahan soup siswa kelas XI TB 3 SMKN 1 Dlanggu Kabupaten Mojokerto tahun pelajaran 2019/2020.

\section{Metode}

Penelitian ini termasuk kedalam jenis penelitian tindakan kelas yang terbagi dalam dua siklus. Pada siklus pertama peneliti melakukan pembelajaran Pengolahan soup, khususnya yang berbentuk kental (thick soup) dengan perlakuan model pembelajaran STAD. Siklus selanjutnya dilakukan dengan mengacu pada hasil refleksi siklus sebelumnya. Setiap siklus terdiri atas empat kegiatan, yaitu perencanaan, tindakan, pengamatan, dan refleksi. Model pembelajaran yang dipilih peneliti adalah menggunakan mode kooperatif tipe Students Teams Achievement Divisions (STAD). Model ini peneliti ambil dengan dasar bahwa untuk meningkatkan kompetensi siswa tidak hanya didapat dari guru sebgai sumber utama, namun juga sikap tolong-menolong dalam tim untuk menyelesaikan masalah. Subjek penelitian ini adalah hasil belajar tata boga materi pengolahan soup adalah siswa kelas XI TB 3 SMKN 1 Dlanggu Kabupaten Mojokerto Tapel. 2019/2020. Subjek penelitian ini memiliki ciri (1) pernah mendapatkan materi stock dan mengaplikasikannya dalam pembuatan kaldu di kelas XI kompetensi keahlian Tata Boga, (2) berjumlah 35 siswa, (3) mayoritas adalah perempuan sejumlah 31, (4) berlatar belakang kompetensi keahlian tata boga dengan wali kelas Dra. Lugiati. Dalam penelitian tindakan kelas ini, peneliti dibantu oleh seorang observer, yaitu Nelis Susanti selaku guru Tata Boga kelas XI. Guru ini bertugas mengamati proses pelaksanaan kegiatan belajar-mengajar ketika peneliti melakukan kegiatan pembelajaran.

Teknik pengumpulan data dengan memberikan tes hasil belajar kepada siswa. Dalam penelitian tindakan kelas ini, instrumen pengumpulan datanya adalah peneliti sebagai instrumen utama yang melaksnakan kegiatan pembelajaran. Instrumen lainnya adalah pedoman observasi dan soal-soal pemahanan. Observer cukup membari tanda ceklis pada lembar observasi yang telah disediakan oleh peneliti, sedangkan soal pemahaman diisi oleh siswa. Analisis data dilakukan setelah data penelitian terkumpul seluruhnya, baik data yang berasal dari model kooperatif tipe students teams achievement divisions (STAD) maupun hasil belajar siswa, pre-test, maupun post-test. Data-data mentah yang telah terkumpul tersebut kemudian diolah dan dianalisis. Teknik analisis data yang digunakan adalah teknik analisis data statistik deskriptif kuantitatif, yang digunakan untuk mendapatkan gambaran penyebaran data penelitian masing-masing variabel sebagaimana adanya, tanpa membuat kesimpulan yang berlaku untuk umum. Data mentah yang telah dikumpulkan perlu diolah dan diringkas agar dapat dideskripsikan dan mudah dipahami.

\section{Hasil dan Pembahasan}

Data hasil pretes kelompok siswa sebelum mendapat pembelajaran dengan menggunakan model pembelajaran kooperatif tipe Students Teams Achievement Divisions (STAD) dianalisis dan untuk mengetahui tingkat pengetahuan dan pemahaman tentang materi belajar yang berhubungan dengan Pengolahan soup. Hasil belajar siswa pra siklus dapat dilihat pada Tabel 1.

Tabel 1. Hasil Belajar Siswa Pra Siklus

\begin{tabular}{|c|c|c|}
\hline No. & Aspek Pengolahan dan Penyajian Soup & Rata-Rata Nilai \\
\hline 1 & Konsistensi & 62 \\
\hline 2 & Warna & 63 \\
\hline 3 & Rasa & 63 \\
\hline & Rata-Rata Nilai & 62,67 \\
\hline
\end{tabular}


Berdasarkan isi Tabel 1 terlihat bahwa nilai pretes kelompok siswa sebelum mendapat perlakuan pembelajaran dengan model pembelajaran kooperatif tipe Students Teams Achievement Divisions (STAD)adalah 62,67.

Perencanaan tindakan siklus 1 dimulai dengan membentuk kelompok diskusi. Siswa yang berjumlah 35 siswa dibagi menjadi 7 kelompok sehingga masing-masing kelompok berjumlah 5 siswa. Materi pelajaran yang diajarkan pada siklus 1 ini adalah pokok bahasan Pengolahan soup. Proses pembelajaran ini menggunakan kooperatif tipe Students Teams Achievement Divisions (STAD) yang diterapkan oleh guru secara langsung dalam pembelajaran di kelas.

Kegiatan yang dilakukan oleh peneliti pada tahap perencanaan adalah: (a) peneliti melakukan analisis kurikulum untuk menentukan standar kompetensi dan kompetensi dasar yang disampaikan kepada siswa dengan menggunakan pembelajaran dengan STAD dan membuat RPP siklus I dengan model pembelajaran STAD; (b) membuat lembar observasi siklus I untuk melihat bagaimana kondisi belajar mengajar dikelas ketika latihan dan kerja kelompok dilaksanakan; (c) membuat lembar kerja siswa siklus 1; (d) membentuk kelompok (terdiri dari 5 siswa) yang bersifat heterogen baik dari segi kemampuan akademis, jenis pembelajaran dengan model kooperatif tipe Students Teams Achievement Divisions (STAD) pada siklus 1; (e) menyusun alat evaluasi pembelajaran berdasarkan perkembangan pada siklus 1 serta menyiapkan instrumen pendukung pembelajaran lainnya.

Pelaksanaan Tindakan Siklus 1 kegiatan belajar mengajar pembelajaran dengan model Kooperatif Tipe Students Teams Achievement Divisions (STAD) untuk siklus I dengan jumlah siswa 35 siswa. Dalam hal ini Peneliti bertindak sebagai guru. Pengamatan (observasi) dilaksanakan bersamaan dengan pelaksanaan pembelajaran. Pelaksanaan tindakan siklus I dapat diuraikan sebagai berikut: (a) guru mengawali pembelajaran dengan mengucapkan salam dan menanyakan jumlah siswa yang hadir; (b) guru melaksanakan apersepsi; (c) guru membagi siswa dalam kelompok diskusi, kemudian memberi tugas yang berkaitan dengan penggunaan pembelajaran pendekatan permainan; (d) guru memberi tugas kepada siswa untuk mempresentasikan di depan kelas hal-hal yang berkaitan dengan materi Pengolahan soup dengan menggunakan pembelajaran $S T A D$, waktu untuk presentasi adalah 3 menit untuk masingmasing individu; (e) guru menindaklanjuti pembelajaran itu dengan menerangkan materi pelajaran tentang hal-hal yang berkaitan dengan materi Pengolahan soup menggunakan pembelajaran STAD, waktu yang digunakan selama 10 menit; (f) guru bersama-sama siswa mendemonstrasikan penerapan pembelajaran Kooperatif Tipe Students Teams Achievement Divisions (STAD) materi pengolahan soup selama 10 menit; (g) guru bersama-sama siswa melukukan kegiatan praktek dengan materi pengolahan soup; (h) guru memberikan tugas secara individu selama 15 menit; (i) guru menutup pelajaran dengan mengucapkan salam. Dalam siklus pertama ini, berdasarkan catatan peneliti, siswa masih kurang dapat bekerja sama, kerja kelompok masih kurang dapat berjalan sebagaimana yang diharapkan, presentasi belum banyak mendapat perhatian/tanggapan dari pendengar (siswa dari kelompok lain). Selama pembelajaran berlangsung dilakukan observasi untuk mengetahui pengaruh kegiatan pembelajaran dalam meningkatkan hasil belajar siswa dalam model pembelajaran Kooperatif Tipe Students Teams Achievement Divisions (STAD) dengan materi Pengolahan soup Pada pembelajaran ini siswa yang masuk sebanyak 35 siswa.

Guru mengamati, ternyata pada setiap kelompok masih didapati siswa yang kurang memperhatikan pelajaran yang berkaitan dengan Pengolahan soup dan masih berbicara dengan teman didekatnya tentang hal-hal yang tidak berkaitan dengan materi pembelajaran. Melalui serangkaian pertanyaan yang disampaikan kepada siswa, sebagian diantaranya belum memahami dan bahkan tidak tau apa yang di diskusikan dalam kelompoknya.

Predikat ketuntasan didapat dengan kriteria nilai rata-rata dari aspek konsistensi, warna, dan rasa minimal 75. Adapun hasil belajar siswa setelah kegiatan yang diberikan dalam Siklus I, dapat dilihat pada Tabel 2.

Tabel 2. Hasil Belajar Siswa dalam Siklus 1

\begin{tabular}{lccccc}
\hline \multicolumn{1}{c}{ Nama Siswa } & $\begin{array}{c}\text { Konsis } \\
\text { Tensi }\end{array}$ & Warna & Rasa & Nilai & Predikat \\
\hline Adelia Maretha Putri & 70 & 70 & 80 & 73.33 & Tidak Tuntas \\
Agustina Ayu Wulandari & 70 & 70 & 70 & 70 & Tidak Tuntas \\
Alfin Maziatuz Zahroh & 70 & 70 & 70 & 70 & Tidak Tuntas \\
Almaidahtul Khamiah & 70 & 70 & 80 & 73.33 & Tidak Tuntas \\
Anggie Mutia Rengganis & 60 & 60 & 60 & 60 & Tidak Tuntas \\
Anisa Sisillah & 60 & 70 & 80 & 70 & Tidak Tuntas \\
\hline
\end{tabular}




\begin{tabular}{|c|c|c|c|c|c|}
\hline Nama Siswa & $\begin{array}{c}\text { Konsis } \\
\text { Tensi }\end{array}$ & Warna & Rasa & Nilai & Predikat \\
\hline Arike Deva Tri Apriliana & 70 & 70 & 70 & 70 & Tidak Tuntas \\
\hline Dea Wahyuni Maslukha & 80 & 70 & 80 & 76.67 & Tuntas \\
\hline Dela Ayu Silviana Putri & 50 & 50 & 50 & 50 & Tidak Tuntas \\
\hline Dinda Rahmawati & 60 & 60 & 80 & 66.67 & Tidak Tuntas \\
\hline Egik Asharta & 70 & 70 & 70 & 70 & Tidak Tuntas \\
\hline Eka Haris Saputra & 70 & 70 & 70 & 70 & Tidak Tuntas \\
\hline Fira Nadzifa Nur Qolby & 70 & 90 & 70 & 76.67 & Tuntas \\
\hline Hadaa Iqadhata Bahjah & 60 & 70 & 60 & 63.33 & Tidak Tuntas \\
\hline Lidhia Maharani & 75 & 75 & 75 & 75 & Tuntas \\
\hline M. Nahrulwahyu Pamungkas & 70 & 70 & 70 & 70 & Tidak Tuntas \\
\hline M.Miftakhul Fauzan & 60 & 60 & 60 & 60 & Tidak Tuntas \\
\hline Meyla Khofidhotul Rofi'ah & 80 & 70 & 80 & 76.67 & Tuntas \\
\hline Mohamad Abdal Fadilah & 60 & 60 & 80 & 66.67 & Tidak Tuntas \\
\hline Muhammad Akbar Firdaus Sonny Ilhamsyah & 90 & 90 & 90 & 90 & Tuntas \\
\hline Muhammad Rifqi Maulana & 80 & 80 & 80 & 80 & Tuntas \\
\hline Nabilah Sestri Nur Aini & 60 & 60 & 60 & 60 & Tidak Tuntas \\
\hline Nengrum Wulan Sari & 60 & 60 & 80 & 66.67 & Tidak Tuntas \\
\hline Oktavian Putri Rahmadani & 80 & 80 & 80 & 80 & Tuntas \\
\hline Rahma Aulia Salsabila & 60 & 60 & 60 & 60 & Tidak Tuntas \\
\hline Refo Abram Primanda & 80 & 70 & 80 & 76.67 & Tuntas \\
\hline Rifatush Ummah & 60 & 60 & 60 & 60 & Tidak Tuntas \\
\hline Rinda Kharisma & 70 & 70 & 80 & 73.33 & Tidak Tuntas \\
\hline Serli Vebrianti & 80 & 80 & 80 & 80 & Tuntas \\
\hline Shinta Talia Febriana & 70 & 70 & 70 & 70 & Tidak Tuntas \\
\hline Siti Hamidah & 70 & 70 & 80 & 73.33 & Tidak Tuntas \\
\hline St. Aisyah Noer Islamy & 70 & 70 & 70 & 70 & Tidak Tuntas \\
\hline Uswatun Khasanah & 80 & 80 & 80 & 80 & Tuntas \\
\hline Wanda Nur Fitriani & 70 & 70 & 70 & 70 & Tidak Tuntas \\
\hline Yolanda Putri Cecillia & 80 & 80 & 80 & 80 & Tuntas \\
\hline Jumlah & & \multicolumn{4}{|c|}{2478.33} \\
\hline Rata-Rata & & \multicolumn{4}{|c|}{70.81} \\
\hline
\end{tabular}

Dari Tabel di atas dapat diketahui bahwa dengan menerapkan pembelajaran kooperatif tipe Students Teams Achievement Divisions (STAD) tampak bahwa nilai rata-rata siswa adalah 70,81 dengan nilai terendah 50 dan nilai tertinggi 90. Nilai ketuntasan belajar adalah 7 jumlah siswa yang mendapat nilai $\geq 75$ sebanyak 21 siswa, yang berarti 60\% dari sejumlah 35 siswa memiliki nilai di atas taraf penguasaan konsep yang diberikan, lebih kecil dari persentase ketuntasan yang dikehendaki yaitu sebesar $95 \%$. Hal ini disebabkan karena siswa masih baru dan asing terhadap metode baru yang diterapkan dalam proses belajar mengajar. Sehingga dapat dikatakan siswa belum banyak memahami tentang konsep pokok bahasan yang dibahas.

Dalam pelaksanaan kegiatan belajar mengajar pada siklus 1 yang masih terdapat kekurangankekurangan, Maka perlu adanya revisi untuk dilakukan pada siklus 2 antara lain: (a) guru dalam memotifasi siswa hendaknya dapat membuat siswa lebih termotivasi selama proses belajar mengajar berlangsung; (b) guru harus lebih dekat dengan siswa sehingga tidak ada perasaan takut dalam diri siswa, sehingga siswa lebih berkosentrasi dalam pembelajaran, (c) guru harus lebih bersabar dalam membimbing siswa berdiskusi untuk menemukan hal-hal baru yang berkaitan dengan materi pembelajaran, d) Guru secara intensif memberikan pengertian kepada siswa kondisi dalam berkelompok, kerTatama kelompok, dan keikutsertaan siswa dalam kelompok; (e) guru mengubah formasi siswa dalam kelompok; (f) guru membantu kelompok yang belum memahami langkah-langkah pembelajaran STAD; (g) guru memberikan dorongan dan motivasi kepada siswa untuk lebih aktif mencari sumber belajar, diharapkan agar siswa memperoleh hasil yang diharapkan.

Perencanaan Tindakan Siklus 2 dimulai dengan membentuk kelompok diskusi. Siswa yang berjumlah 35 siswa dibagi menjadi 7 kelompok sehingga masing-masing kelompok berjumlah 5 siswa. Materi pelajaran yang diajarkan pada siklus II ini tetap pada pokok pengolahan soup. Proses pembelajaran pokok bahasan ini menggunakan model STAD yang diterapkan oleh guru secara langsung dalam pembelajaran di kelas. 
Kegiatan yang dilakukan oleh peneliti pada tahap perencanaan pada siklus 2 yaitu: (a) peneliti melakukan analisis kurikulum untuk menentukan standar kompetensi dan kompetensi dasar yang disampaikan kepada siswa dengan menggunakan pembelajaran STAD; (b) membuat RPP dengan model pembelajaran kooperatif tipe Students Teams Achievement Divisions (STAD) siklus 2; (c) membuat lembar observasi siklus 2 untuk melihat bagaimana kondisi belajar mengajar di kelas ketika latihan dan kerja kelompok dilaksanakan; (d) membuat lembar kerja siswa siklus 2; (e) membentuk kelompok (terdiri dari 5 siswa) yang bersifat heterogen baik dari segi kemampuan akademis, dengan menggunakan pembelajaran kooperatif tipe Students Teams Achievement Divisions (STAD) pada siklus 2; (f) menyusun alat evaluasi pembelajaran berdasarkan perkembangan pada siklus II serta menyiapkan instrumen pendukung pembelajaran lainnya.

Pelaksanaan kegiatan belajar mengajar dengan model pembelajaran pendekatan permainan untuk siklus 2 dilaksanakan di kelas XI TB 3 SMKN 1 Dlanggu dengan jumlah siswa 35. siswi materi pengolahan soup. Dalam hal ini Peneliti bertindak sebagai guru. Pengamatan (observasi) dilaksanakan bersamaan dengan pelaksanaan pembelajaran. Pelaksanaan tindakan disesuaikan dengan RPP (Rencana Pelaksanaan Pembelajaran) dan lembar kerja yang telah dibuat dan mengacu pada revisi siklus 1 , sehingga kekurangan-kekurangan pada siklus I tidak terulang pada siklus 2. Adapun proses belajar mengajar mengacu pada rencana pembelajaran yang telah dipersiapkan dengan menggunakan pembelajaran $S T A D$, dengan tahapan, presentasi kelas, kerja kelompok, tes individu,dan penghargaan kelompok.

Pelaksanaan tindakan siklus II dapat diuraikan sebagai berikut: (a) guru mengawali pembelajaran dengan mengucapkan salam dan menanyakan jumlah siswa yang hadir; (b) guru melaksanakan apersepsi; (c) guru membagi siswa dalam kelompok diskusi, kemudian memberi tugas yang berkaitan dengan penggunaan model pembelajaran; (d) guru memberi tugas kepada siswa untuk mempresentasikan di depan kelas hal-hal yang berkaitan Pengolahan soup atas dengan menggunaan model pembelajaran STAD, waktu untuk presentasi adalah 3 menit untuk masing-masing kelompok; (e) guru menindaklanjuti pembelajaran itu dengan menerangkan materi pelajaran tentang hal-hal yang berkaitan pengolahan soup atas menggunakan model pembelajaran Kooperatif Tipe Students Teams Achievement Divisions (STAD) waktu yang digunakan selama 10 menit; (f) guru bersama-sama siswa mendemonstrasikan penggunaan pembelajara materi Pengolahan soup atas selama 10 menit; (g) guru bersama-sama siswa melukukan pembelajaran dengan materi pengolahan soup; (h) guru memberikan tugas secara individu selama 15 menit; (i) guru menutup pelajaran dengan mengucapkan salam.

Hasil Tindakan Siklus 2 selama pembelajaran berlangsung dilakukan observasi untuk mengetahui penerapan model pembelajaran kooperatif tipe Students Teams Achievement Divisions (STAD) dalam meningkatkan hasil belajar siswa dalam proses pembelajaran materi pengolahan soup. Pada pembelajaran ini siswa yang masuk sebanyak 35. siswa.

Bila dilihat dari angka aktivitas guru dan siswa selama kegiatan belajar mengajar, maka secara keseluruhan aktivitas guru dan siswa menunjukkan pembelajaran yang berorientasi pembelajaran keterampilan proses dalam setting pembelajaran kooperatif tipe Students Teams Achievement Divisions $(S T A D)$ berpusat pada siswa, dimana siswa terlibat aktif dalam pembelajaran. Pada akhir proses belajar mengajar siklus II siswa diberi tes dengan tujuan untuk mengetahui tingkat keberhasilan siswa dalam proses belajar mengajar yang sudah dilakukan di siklus 1, kemudian dikomparasikan dengan hasil pada siklus 2 .

Dalam pembelajaran siklus 2, konsep-konsep yang teridentifikasi dikembangkan lebih lanjut. Dalam Siklus 2 ini, berdasarkan catatan peneliti, kerjasama siswa sudah berjalan dengan baik, sehingga masing-masing siswa dapat memecahkan masalah secara individual. Adapun nilai tes formatif siswa dalam siklus 2 dapat dilihat pada Tabel 3.

Tabel 3. Nilai Tes Formatif Siswa dalam Siklus 2

\begin{tabular}{lccccc}
\hline \multicolumn{1}{c}{ Nama Siswa } & $\begin{array}{c}\text { Konsis } \\
\text { Tensi }\end{array}$ & Warna & Rasa & Nilai & Predikat \\
\hline Adelia Maretha Putri & 80 & 80 & 80 & 80 & Tuntas \\
Agustina Ayu Wulandari & 80 & 80 & 80 & 80 & Tuntas \\
Alfin Maziatuz Zahroh & 80 & 80 & 90 & 83.33 & Tuntas \\
Almaidahtul Khamiah & 70 & 70 & 70 & 70 & Tidak Tuntas \\
Anggie Mutia Rengganis & 70 & 80 & 90 & 80 & Tuntas \\
Anisa Sisillah & 80 & 80 & 80 & 80 & Tuntas \\
Arike Deva Tri Apriliana & 90 & 80 & 90 & 86.67 & Tuntas \\
Dea Wahyuni Maslukha & 60 & 60 & 60 & 60 & Tidak Tuntas \\
\hline
\end{tabular}




\begin{tabular}{|c|c|c|c|c|c|}
\hline Nama Siswa & $\begin{array}{c}\text { Konsis } \\
\text { Tensi } \\
\end{array}$ & Warna & Rasa & Nilai & Predikat \\
\hline Dela Ayu Silviana Putri & 70 & 70 & 90 & 76.67 & Tuntas \\
\hline Dinda Rahmawati & 80 & 80 & 80 & 80 & Tuntas \\
\hline Egik Asharta & 80 & 80 & 80 & 80 & Tuntas \\
\hline Eka Haris Saputra & 80 & 90 & 80 & 83.33 & Tuntas \\
\hline Fira Nadzifa Nur Qolby & 70 & 80 & 70 & 73.33 & Tidak Tuntas \\
\hline Hadaa Iqadhata Bahjah & 85 & 85 & 85 & 85 & Tuntas \\
\hline Lidhia Maharani & 80 & 80 & 80 & 80 & Tuntas \\
\hline M. Nahrulwahyu Pamungkas & 70 & 70 & 70 & 70 & Tidak Tuntas \\
\hline M.Miftakhul Fauzan & 90 & 80 & 90 & 86.67 & Tuntas \\
\hline Meyla Khofidhotul Rofi'ah & 70 & 70 & 90 & 76.67 & Tuntas \\
\hline Mohamad Abdal Fadilah & 90 & 90 & 90 & 90 & Tuntas \\
\hline Muhammad Akbar Firdaus Sonny Ilhamsyah & 90 & 90 & 90 & 90 & Tuntas \\
\hline Muhammad Rifqi Maulana & 70 & 70 & 70 & 70 & Tidak Tuntas \\
\hline Nabilah Sestri Nur Aini & 70 & 70 & 90 & 76.67 & Tuntas \\
\hline Nengrum Wulan Sari & 90 & 80 & 90 & 86.67 & Tuntas \\
\hline Oktavian Putri Rahmadani & 70 & 70 & 70 & 70 & Tidak Tuntas \\
\hline Rahma Aulia Salsabila & 90 & 80 & 90 & 86.67 & Tuntas \\
\hline Refo Abram Primanda & 70 & 70 & 70 & 70 & Tidak Tuntas \\
\hline Rifatush Ummah & 80 & 80 & 90 & 83.33 & Tuntas \\
\hline Rinda Kharisma & 90 & 90 & 90 & 90 & Tuntas \\
\hline Serli Vebrianti & 80 & 80 & 80 & 80 & Tuntas \\
\hline Shinta Talia Febriana & 80 & 80 & 90 & 83.33 & Tuntas \\
\hline Siti Hamidah & 80 & 80 & 80 & 80 & Tuntas \\
\hline St. Aisyah Noer Islamy & 90 & 80 & 90 & 86.67 & Tuntas \\
\hline Uswatun Khasanah & 80 & 80 & 80 & 80 & Tuntas \\
\hline Wanda Nur Fitriani & 90 & 80 & 90 & 86.67 & Tuntas \\
\hline Yolanda Putri Cecillia & 80 & 80 & 80 & 80 & Tuntas \\
\hline Jumlah & & & & 80.1429 & \\
\hline Rata-Rata & & & & 83.33 & \\
\hline
\end{tabular}

Dari tabel di atas tampak bahwa hasil nilai evaluasi rata-rata siswa secara individual adalah 83,33 dengan nilai terendah 60 dan nilai tertinggi 90. Data diatas menunjukkan bahwa pada siklus 2 ini, nilai siswa secara individual mengalami peningkatan, yaitu siswa yang tuntas sebanyak 32 siswa dan yang belum tuntas sebanyak 3 siswa, yang berarti 95\% dari sejumlah 35 siswa memiliki nilai di atas taraf penguasaan konsep yang diberikan. Dari siklus 2 ini dapat dikatakan bahwa proses pembelajaran dengan model pembelajaran kooperatif tipe Students Teams Achievement Divisions (STAD) dapat meningkatkan hasil belajar siswa.

Dalam pelaksanaan kegiatan belajar mengajar pada siklus 2 ini masih terdapat kekurangankekurangan. Pada tahap ini akan merefleksikan kembali apa yang telah dilaksanakan selama penelitian tindakan kelas dilakukan. Dari data yang diperoleh dapat diuraikan sebagai berikut: (a) selama proses belajar mengajar guru telah melaksanakan pembelajaran dengan cukup baik dengan model pembelajaran $S T A D$, meskipun ada beberapa bagian yang masih belum sempurna, tetapi presentasi pelaksanaan untuk masing-masing kegiatan sudah cukup baik; (b) berdasarkan data hasil lembar observasi kegiatan kelompok siswa, diadakan perubahan jumlah kelompok pada siklus 1 sebanyak 7 siswa, dan pada siklus 2 sebanyak 3 siswa; (c) kekurangan pada siklus 1 diperbaiki, sehingga pembelajaran menjadi lebih baik pada siklus 2; (d) hasil evaluasi siswa mengalami peningkatan dari siklus 1 ke siklus II, dan telah mencapai ketuntasan belajar pada siklus 2 ini sesuai yang diharapkan yakni peningkatan hasil belajar siswa.

Pembahasan antar siklus sebelum perlakuan diberikan pada masing-masing kelompok, nilai rerata pretes siswa sebelum diberi perlakuan pembelajaran dengan model kooperatif tipe Students Teams Achievement Divisions (STAD) adalah 62,67. Setelah siswa diberi perlakuan pembelajaran dengan model pembelajaran kooperatif tipe Students Teams Achievement Divisions (STAD) pada siklus 1 mengalami peningkatan menjadi 83,33, namun hasil ini belum memenuhi target hasil belajar siswa mata pelajaran pengolahan soup yaitu 95\% . Nilai tes formatif siswa dapat dilihat pada Gambar 1. 


\section{NILAI TES FORMATIF SISWA}

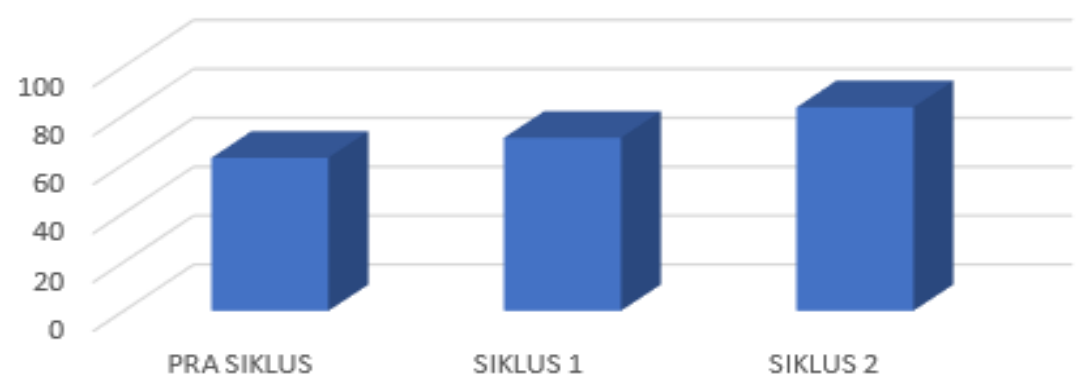

Gambar 1. Perbandingan Nilai Tes Formatis Siswa Antar Siklus

Dari Gambar 1 diatas, dapat dilihat bahwa terjadi rerata pada tahap pra siklus, siklus 1, siklus 2 . Bila dihitung berdasarkan nilai rerata pretes, kelompok siswa yang diberi perlakuan pembelajaran dengan model Kooperatif Tipe Students Teams Achievement Divisions (STAD) setelah dilaksanaknnya siklus ke 2 mengalami peningkatan rerata hasil belajar sebesar 83,33-62,67 =20,66.

Penerapan pembelajaran kooperatif tipe Students Teams Achievement Divisions (STAD) memberikan peningkatatan yang lebih baik pada perolehan hasil belajar Pengolahan soup dari pada penerapan pembelajaran dengan metode lainya. Dengan kata lain dapat diinterpretasikan bahwa penerapan pembelajaran kooperatif tipe Students Teams Achievement Divisions (STAD) dapat meningkatkan perolehan hasil belajar siswa pada materi pengolahan soup dari pada dengan model pembelajaran lainnya.

Model pembelajaran kooperatif tipe Students Teams Achievement Divisions (STAD) adalah suatu metode pembelajaran yang melakukan pemusatan pada pengajaran dan ketrampilan memecahkan masalah, yang diikuti dengan penguatan ketrampilan (Nurhazannah, 2017; Suratno, 2013; Viviyung, 2015). Penggunaan model pembelajaran yang bervariasi dirasa mampu untuk meningkatkan semangat peserta didik dalam mengikuti proses belajar mengajar, karena dengan pembelajaran secara kooperatif semaksimal mungkin partisipasi siswa dalam memperoleh pengetahuan sangat diperlukan.

Kelebihan dari model pembelajaran kooperatif tipe Students Teams Achievement Divisions (STAD) adalah (1) mendorong siswa untuk lebih aktif dalam proses pembelajaran, (2) dapat menumbuhkan rasa ingin tahu siswa, (3) melatih kemampuan berpikir siswa dalam memecahkan masalah, (4) menumbuhkan interaksi antar siswa menunjukan bahwa model pembelajaran tersebut dapat meningkatkan hasil belajar siswa (Kristin, 2016; Sofianti et al., 2013; Wardani, 2015). Hal ini menunjukan bahwa model pembelajaran tersebut dapat meningkatkan aktivitas dan hasil belajar siswa, dengan menerapkan model pembelajaran kooperatif tipe Students Teams Achievement Divisions (STAD) maka siswa akan lebih aktif dan kreatif dalam memecahkan masalah yang dihadapi dalam pembelajaran, dapat meningkatkan ingatan yang lebih kepada siswa mengenai materi pembelajaran yang telah disampaikan, siswa lebih memahami isi materi yang diajarkan karena siswa terlibat langsung dalam proses pembelajaran sehingga hasil belajar siswa akan meningkat.

Penelitian ini didukung dengan beberapa penelitian yang relevan seperti: (1) penelitian yang dilaksanakan oleh (Rahmadani et al., 2018), yang memperoleh hasil bahwa Berdasarkan hasil pengembangan bahan ajar diperoleh modul matematika berbasis model kooperatif tipe STAD dengan metode penemuan terbimbing yang valid, praktis, dan efektif; (2) penelitian yang dilaksanakan oleh (Viviyung, 2015), yang memperoleh hasil bahwa penggunaan model pembelajaran kooperatif tipe STAD dapat meningkatkan hasil belajar PKn; (3) penelitian yang dilaksanakan oleh (Febriana, 2017), yang memperoleh hasil bahwa model pembelajaran berbasis kompetensi dengan pendekatan dunia kerja pada program D3 Tata Boga efektif untuk digunakan didalam proses pembelajaran.

Implikasi penelitian ini adalah dengan perlakuan model STAD dapat mendorong siswa untuk lebih aktif dalam proses pembelajaran, menumbuhkan rasa ingin tahu siswa, dan melatih kemampuan berpikir siswa.

\section{Simpulan}

Berdasarkan analisis hasil dan pembahasan dapat disimpulkan bahwa penerapan model pembelajaran kooperatif tipe Students Teams Achievement Divisions (STAD) dapat meningkatkan perolehan 
hasil belajar siswa pada materi pengolahan soup dari pada dengan model pembelajaran lainnya pada siswa kelas XI TB 3 SMKN 1 Dlanggu Kabupaten Mojokerto tahun pelajaran 2019/2020. Implikasi penelitian ini adalah dengan perlakuan model STAD dapat mendorong siswa untuk lebih aktif dalam proses pembelajaran, menumbuhkan rasa ingin tahu siswa, dan melatih kemampuan berpikir siswa.

\section{Daftar Rujukan}

Arwanda, P., Irianto, S., \& Andriani, A. (2020). Pengembangan Media Pembelajaran Articulate Storyline Kurikulum 2013 Berbasis Kompetensi Peserta Didik Abad 21 Tema 7 Kelas IV Sekolah Dasar. AlMadrasah: Jurnal Pendidikan Madrasah Ibtidaiyah. https://doi.org/10.35931/am.v4i2.331

Astuti, Y., Sonhadji, A., \& Nyoto, A. (2016). Pengembangan Buku Ajar Mata Pelajaran Tata Hidang Paket Keahlian Jasa Boga Sekolah Menengah Kejuruan. Jurnal Pendidikan: Teori, Penelitian, Dan Pengembangan, 1(1). https://doi.org/10.17977/jp.v1i1.6603

Esminarto, E., Sukowati, S., Suryowati, N., \& Anam, K. (2016). Implementasi Model STAD Dalam Meningkatkan Hasil Belajar Siswa. Briliant: Jurnal Riset Dan Konseptual, 1(1), 16. https://doi.org/10.28926/briliant.v1i1.2

Faridah, N., Isrok'atun, I., \& Aeni, A. N. (2016). Pendekatan Open-Ended Untuk Meningkatkan Kemampuan Berpikir Kreatif Matematis Dan Kepercayaan Diri Siswa. Jurnal Pena IIlmiah, 1(1), 1061-1070. https://doi.org/10.23819/pi.v1i1.3025

Febriana, R. (2017). Efektivitas Model Pembelajaran Berbasis Kompetensi Dengan Pendekatan Dunia Kerja Pada Program D3 Tata Boga. Cakrawala Pendidikan: Jurnal Ilmiah Pendidikan, 36(1), 148155. https://doi.org/10.21831/cp.v36i1.8891

Hazmiwati, H. (2018). Penerapan Model Pembelajaran Kooperatif Tipe STAD Untuk Meningkatkan Hasil Belajar IPA Siswa Kelas II Sekolah Dasar. Primary: Jurnal Pendidikan Guru Sekolah Dasar, 7(1), 178. https://doi.org/10.33578/jpfkip.v7i1.5359

Kristin, F. (2016). Efektivitas Model Pembelajaran Kooperatif Tipe STAD Ditinjau Dari Hasil Belajar IPS Siswa Kelas 4 SD. Scholaria: Jurnal Pendidikan Dan Kebudayaan, 6(2), 74-79. https://ejournal.uksw.edu/scholaria/article/view/230

Maharani, A. (2017). Analisis Pengembangan Soal Tes Evaluasi Matematika Berbasis Kemampuan Berpikir Kreatif Untuk Siswa Smk Pada Materi Geometri. Aksioma: Jurnal Pendidikan Matematika FKIP Univ. Muhammadiyah, 6(3), 350-363. https://doi.org/10.1017/CB09781107415324.004

Masdarini, L., \& Devi, M. (2012). Pemahaman, Sikap, Dan Unjuk Kerja Higiene-Sanitasi Siswa Dalam Pengolahan Dan Penyajian Makanan Di SMK Bidang Keahlian Tata Boga. Teknologi Dan Kejuruan, 34(2). https://doi.org/10.17977/tk.v34i2.3029

Maulida, M., Wati, M., \& An'nur, S. (2015). Pengembangan Bahan Ajar Berbasis Pendidikan Karakter Dalam Mendukung Implementasi Kurikulum 2013. Berkala Ilmiah Pendidikan Fisika, 3(1), 11-19. https://doi.org/10.20527/bipf.v3i1.760

Morelent, Y., \& Syofiani. (2018). Pengaruh Penerapan Kurikulum 2013 Terhadap Pembentukan Karakter Siswa Sekolah Dasar Negeri 05 Percobaan Pintu Kabun Bukittinggi. Jurnal Penelitian Bahasa Dan Sastra Indonesia, 1(2), 141-152. https://doi.org/10.22202/jg.2015.v1i2.1234

Nurhazannah, Y. (2017). Meningkatkan Hasil Belajar Siswa Menggunakan Model Pembelajaran Kooperatif Tipe StudentTeam Achievement Devision (STAD). Jurnal Pendidikan Matematika Dan IPA, 8(2), 50-59. https://doi.org/10.26418/jpmipa.v8i2.21176

Prasetyo, A., Hartini, T., Damayani, A., Mushafanah, Q., \& Zahraini, D. A. (2016). IbM Himpaudi Kecamatan Kaliwungu Kendal Dalam Rangka Penyusunan Perangkat Pembelajaran Kurikulum 2013. E-Dimas: Jurnal Pengabdian Kepada Masyarakat, 7(2), 1 - 8. https://doi.org/10.26877/e-dimas.v7i2.1128

Purwanti, K. L. (2017). Penerapan Literasi Lintas Kurikulum Matematika Dalam Pembelajaran Kelas Tinggi Di MIT Nurul Islam Ngaliyan Semarang Tahun 2016. Phenomenon : Jurnal Pendidikan MIPA, 7(1), 79. https://doi.org/10.21580/phen.2017.7.1.1497

Rahmadani, Y., Tayeb, T., \& Baharuddin. (2018). Modul Matematika Berbasis Model Kooperatif Tipe STAD Dengan Metode Penemuan Terbimbing Pada Pokok Bahasan Teorema Phytagoras. Lentera Pendidikan: Jurnal Ilmu Tarbiyah Dan Keguruan, 21(1), 23-32. 
https://doi.org/10.24252/lp.2018v21n1i3

Rudyanto, H. E. (2016). Model Discovery Learning Dengan Pendekatan Saintifik Bermuatan Karakter Untuk Meningkatkan Kemampuan Berpikir Kreatif. Premiere Educandum: Jurnal Pendidikan Dasar Dan Pembelajaran, 4(01), 41-48. https://doi.org/10.25273/pe.v4i01.305

Sofianti, D., Akhirmen, \& Areva, D. (2013). Perbedaan Hasil Belajar Ekonomi Siswa Yang Menggunakan Model Pembelajaran Kooperatif Tipe Think Pair Share (TPS) Dengan Tipe Student Teams Achievement Division (STAD) Siswa Kelas XI IPS SMAN 11 Padang. Economica: Journal of $\begin{array}{llll}\text { Economic and Economic } & \text { Education, 238-244. }\end{array}$ https://doi.org/10.22202/economica.2013.v1.i2.125

Suratno. (2013). Pengaruh Penerapan Metode STAD Terhadap Hasil Belajar Ekonomi Ditinjau Dari Minat Siswa Di SMA N 10 Batanghari. Jurnal Pendidikan Ekonomi Dinamika Pendidikan, 8(2), 111-122. https://doi.org/10.15294/dp.v8i2.3367

Viviyung. (2015). Penggunaan Model Pembelajaran Kooperatif Tipe STAD Untuk Meningkatkan Hasil Belajar PKn Siswa Kelas V SD Negeri 32 Sungai Limau Kabupaten Padang Pariaman. JPPI (Jurnal Penelitian Pendidikan Indonesia), 1(1), 38-46. https://doi.org/10.29210/0201515

Wahyudin, W. (2018). Optimalisasi Peran Kepala Sekolah dalam Implementasi Kurikulum 2013. Jurnal Kependidikan, 6(2), 249-265. https://doi.org/10.24090/jk.v6i2.1932

Wahyuni, P. (2019). The Effect of Cooperative Learning Type Student Teams Achievement Division (STAD) on Understanding Mathematical Concepts in Class VIII Students of MTs N Pekanbaru. International Journal of Trends in Mathematics Education Research, 2(4), 168-172. https://doi.org/10.33122/ijtmer.v2i4.72

Wardani, D. T. (2015). Pengaruh Pembelajaran Kooperatif Tipe Stad (Student Teams Achievement Divisions) Dan Jigsaw Terhadap Prestasi Belajar Ekonomi Ditinjau Dari Motivasi Belajar Siswa Tahun Ajaran 2014/2015. EQUILIBRIUM : Jurnal Ilmiah Ekonomi Dan Pembelajarannya, 3(2), 105112. https://doi.org/10.25273/equilibrium.v3i2.657

Yuliarni, E., Luawo, M. I. R., \& Karsih, K. (2013). Pengaruh Penerapan Model Cooperative Learning Tipe STAD (Student Teams Achievement Division) Dalam Layanan Bimbingan Klasikal Terhadap Keterampilan Belajar Siswa Dalam Membaca Dengan Teknik SQ3R (Studi Pre-Eksperimen Pada Siswa Kelas X-F Di SMAN 8 Bogor). Insight: Jurnal Bimbingan Konseling, 2(1), 25-31. https://doi.org/10.21009/INSIGHT.021.05 